\title{
Pay-as-you-go forensics could hurt British justice
}

London. The introduction of a "customer/ contractor" relationship into the work of Britain's Forensic Science Service (FSS) may have made it harder for defendants to receive fair treatment, according to a report published last week by the Royal Commission on Criminal Justice.

The report, written by Paul Roberts and Chris Willmore of the law faculty at the University of Bristol, is based on a detailed analysis of 24 criminal trials in the Bristol region. It warns that the scope of the service has been limited by its need to satisfy a

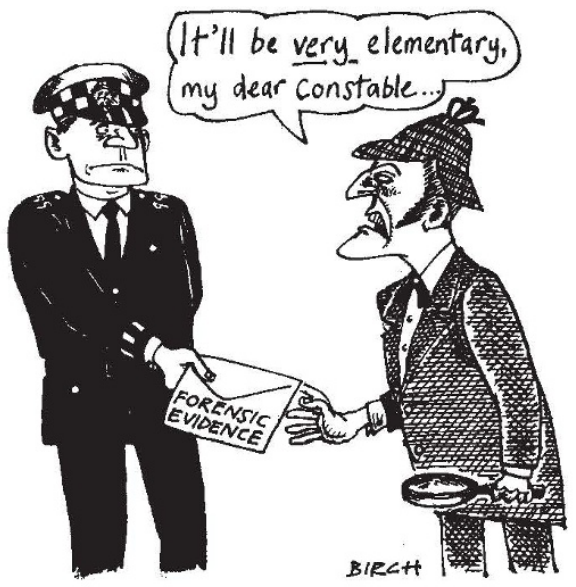

"customer" - namely the police force and that the need to do "what the customer wants" could affect its objectivity.

"Recent changes in the arrangements for payment for forensic science services could induce greater selectivity," the authors warn. "The danger is that forensic science evidence will reflect this selective approach to submission by the police, rather than giving a fair impression of the strength of the case against a defendant."

As an example, the report quotes a case in which the police asked a forensic scientist to compare a footprint found at the scene of a crime with shoes worn by one of several defendants in a court case. When the footprint did not fit, she contacted the police to ask if she had been supplied with all the relevant footwear and discovered that the footprints fitted shoes worn by another defendant, which had not been submitted for examination.

Roberts and Willmore describe this as a striking example of the way in which the choice of what items to submit can be selective. "It is most unlikely that the FSS would ever succumb to overt pressure, whatever the charging arrangements", they write. "Nevertheless, direct charging has perhaps increased FSS susceptibility to more subtle pressure."
In the past, the FSS was fully integrated into the Home Office. Since April 1991, however, it has been an independent, selfsupporting body, and the police are now required to pay a fee for each item submitted for analysis.

According to one forensic scientist quoted anonymously in the report, the number of items submitted to her laboratory for analysis has fallen by 20 per cent since the introduction of direct charging. Even official statistics published by the FSS confirm a drop of 4 per cent in demand in its first year as an independent agency.

FSS officials say that the reduced demand may indicate that more cost-effective use is being made of the service. But another former member of the FSS, who was a defence witness in court cases, said that the new charging system is encouraging the police to submit only items thought to assist in securing a conviction. "Because they are paying on the basis of items sent to the laboratory, [the police] will be very selective in what they send," she is quoted as saying.

Criticism of the new procedures is backed by the Institute of Professionals, Managers and Specialists (IPMS), the trade union that represents 800 scientists working for the Home Office. "Direct charging can mean that the wrong decisions are being taken into account", Steve Jary of IPMS said last week. "Part of the problem is that the customer for the FSS should not just be the police or the prosecution services, but also the courts and the general public."

The report, which was prepared for the Royal Commission as part of its inquiry into the workings of the forensic science service following a number of recent miscarriages of justice, points out that many scientists working for the FSS feel that they should play a more active role in deciding how investigations should be carried out.

At the same time, the report emphasizes that all scientific evidence needs to be approached with caution. "Although science can have great utility in a forensic context, the risk of overreliance is obvious and attested to by the recent miscarriage cases," it says. "There can be genuine disagreement between forensic scientists just as there can be disagreement between nuclear physicists."

\section{David Dickson}

\section{Correction}

An official of the US Agency for International Development was improperly mentioned in a recent article on Indian protests against a seed gene bank under construction (see Nature 361, 291; 1993). The official, Joel Cohen, did not speak to the author of the article.

\section{Strasbourg picked as permanent home for space college}

Munich. Strasbourg has been chosen as the permanent home of the International Space University (ISU), which plans by 1995 to expand into an established graduate college.

The ISU, funded by government space agencies including the US National Aeronautics and Space Administration (NASA) and the European Space Agency (ESA), is temporarily based in Cambridge, Massachusetts. Founded in 1987 to promote international collaboration in space science, it began as a summer-school programme offering a ten-week course to some 130 graduate-level students, but the intention was always to become a permanent university.

The university will offer a single, diverse programme leading to a Master of Space Studies degree. The 10-month course will cover all aspects of space science, from physical sciences and satellite application to international policy and law, and will include a two-month practical project involving design of an international space mission. Initial enrolment is projected at 100 , with double this number by the year 2000. Permanent and visiting faculty will number $20-40$, and a $\mathrm{PhD}$ programme is a possibility. The ISU will be located within Strasbourg's Université Louis Pasteur.

Strasbourg was chosen over six competitors because of its international prospects and its strong academic reputation. The city and Alsace regional authorities have pledged the ECU28 million (US\$36 million) needed to get the project under way, and various sources, including ESA, some national space agencies and industry have pledged to meet the annual running cost of ECU6 million. City officials have six months to turn the pledges into reality.

Space scientists welcome the school's interdisciplinary and international approach to space research. At least 18 universities around the world have applied to become affiliate campuses, contributing to teaching on site and in their own establishments. Tony MacDonnell of the University of Kent's department of space studies believes that contact "with the internationally minded, young community of scientists that the ISU attracts" will be stimulating and that the students, with their broad education, will help to make space science more international.

Many of the students are likely to be seconded by industry. Those from academic backgrounds, says ISU spokesman Sterling North, are likely upon graduation to pursue management posts with space agencies.

Alison Abbott 